\section{Kastamonu Eğitim Dergisi Kastamonu Education Journal}

Eylül 2019 Cilt:27 Sayı:5

kefdergi.kastamonu.edu.tr
Başvuru Tarihi/Received: 01.05.2019

Kabul Tarihi/Accepted: 24.05.2019

DOI: $10.24106 /$ kefdergi.3776

\title{
Okul Öncesi Öğretmenlerinin Üstün Yetenekli Çocuklara Yönelik Algı ve Eğitim İhtiyaçlarının Belirlenmesi
}

\section{Determination of Preschool Teachers' Perceptions and Training Needs towards Gifted and Talented}

\section{Öz}

\author{
Deniz ÖZCAN ${ }^{1}$, Şener GÜLKAYA ${ }^{2}$
}

Bu araştırmada, okul öncesi öğretmenlerinin üstün yetenekli öğrencilere yönelik algıları ve eğitim ihtiyaçlarının belirlenmesi amaçlanmıştır. Tarama modeli niteliğinde olan araştırmanın evreni Kuzey Kıbrıs'ta Milli Eğitim ve Kültür Bakanlığı İlköğretim kademesinde olan 99 ilköğretim okulunda ve 13 anaokulunda görev yapan okul öncesi öğretmenleri oluştururken, ölçek ve anketi hatasız doldurulan 100 okul öncesi öğretmeni araştırmanın örneklemini oluşturmaktadır. Veri toplama aracı olarak Demirok ve Özcan tarafindan geliştirilen "Üstün Yetenekli Öğrencilere Yönelik Algı Ölçeği" ve Demirok tarafindan geliştirilen "Üstün Yetenekli Öğrencilere Yönelik Eğitim ìntiyacı Anketi" kullanılmıştr. Araşttrmada verilerin çözümlenmesinde aritmetik ortalama, standart sapma, en düşük ve en yüksek değerler, parametrik testler olan t-testi ve tek faktörlü varyans (One-Way ANOVA), parametrik olmayan testlerden ise Mann-Whitney U ve Kruskal Wallis Testi kullanılmıştr. Araştırmada, okul öncesi öğretmenlerinin üstün yetenekli öğrencilere yönelik algılarının olumlu yönde olduğu sonucuna ulaşıımıştır. Okul öncesi öğretmenlerinin üstün yetenekli öğrencilere yönelik eğitim ihtiyaçlarının belirlenmesindeki ortalama puanı "çok ihtiyaç hissediyorum" sınırları içerisinde belirlenmiştir.

Anahtar Kelime: algı, eğitim ihtiyacı, okul öncesi öğretmeni, üstün yetenek

\section{Abstract}

This study aims to determine the perceptions and trainning needs of preschool teachers towards gifted and talented students. The population of the study consists of 100 pre-school teachers. Descriptive research model has been used in as method of the study. "Perception Scale for Gifted Students" developed by Demirok and Ozcan, and "Tranning needs questionnaire'developed by Demirok have been used as data collection tools. In analyzing the research data, arithmetic average, standard deviation, minimum and maximum values, parametric tests, $t$-test and one way variance (one-way ANOVA) non-parametric tests, Mann-Whitney $\mathrm{U}$ and Kruskal Wallis test were used. The ANOVA test to determine the differences in the after math of a complementary post-hoc analysis The results were interpreted and the analysis has been converted into a data table. Results of the study have stated that while pre-school teachers have positive perception towards gifted students, they need training about gifted and talented students.

Keywords: perception, trainning needs, pre-school teachers, giftedness 


\section{Extended Abstract}

Purpose of the study: This study aims to determine the perceptions and trainning needs of preschool teachers towards gifted and talented students. To reach this aim, the study seeks to answer following questions.

1. How is the general perceptions of preschool teachers towards gifted children?

2. Are there any significant difference among the perceptions of preschool teachers towards gifted children regard to their;

2.1. age

2.2. professional seniority

2.3. participation in in-service trainning

2.4. where they reached the sources

3. What are the educational needs of preschool teachers towards gifted children?

Methodology: Descriptive research model has been used in as method of the study. The population of the study consists of 100 pre-school teachers workin in North Cyprus. "Perception Scale for Gifted Students" developed by Demirok and Ozcan (2016), and "Tranning needs questionnaire'developed by Demirok (2012) have been used as data collection tools. In analyzing the research data, arithmetic average, standard deviation, minimum and maximum values, parametric tests, t-test and one way variance (one-way ANOVA) non-parametric tests, Mann-Whitney $\mathrm{U}$ and Kruskal Wallis test were used. The ANOVA test to determine the differences in the after math of a complementary post-hoc analysis The results were interpreted and the analysis has been converted into a data table.

Results and Conclusion: The average score of the perceptions of preschool teachers towards gifted students was determined within the limits of agree. This finding can be interpreted that preschool teachers' perceptions of gifted students are positive even if they are not in the range. There was no significant difference between the perceptions of pre-school teachers in terms of their gender on 'willingness to learn', 'characteristics of expression', 'personality traits', 'learning characteristics', and 'mental characteristics' dimensions. However, according to the results of comparison of the average scores of the pre-school teachers towards the gifted students according to their ages, there is a significant difference between the perceptions of preschool teachers.it is seen in the dimensions on gifted students' "willingness to learn', 'expressing characteristics', 'learning characteristics' and 'mental characteristics' and in general. Young teachers have more positive perceptions towards gifted education than older. In addition to this, significant differences have been found according to preschool teachers' professional seniority. Teachers having one to ten years professional seniority have more positive perceptions than the teachers having more than ten years seniority. This results also supports the results obtained from the age variable. Moreover, significant difference has been found between the perceptions of preschool teachers towards gifted student regarding participation in in-service training about giftedness. Teachers participating in-service training about giftedness have more positive perceptions than the teachers not participate in this training. Furthermore, according to the results, it has been found that there is a meaningful difference among the perceptions of preschool teachers towards gifted students in terms of where they reach the sources about gifted students. Preschool teachers using the internet that is online sources have more positive perceptions than the teachers preferring books and experts in the field. As a last result, according to the education needs of pre-school teachers participating in the research for gifted students, the average score of the educational needs of preschool teachers for gifted students is determined within the limits of 'I feel very needed'. It can be said that preschool teachers do not have enough knowledge about education and gifted students.

Breifly, results of the study have stated that while pre-school teachers have positive perception towards gifted students, they need training about gifted and talented students. 


\section{Giriş}

Erken çocukluk döneminde, çocukların özellikleri bilinmeden ve bilinçsizce yapılan eğitim çocuğun tüm yaşamını olumsuz yönde etkileyecek bir sürecin başlangıcı olabilir. Bu noktada çocuklara verilecek nitelikli ve sağlıklı bir eğitim onların geleceğini belirleme de önemli bir rol oynamaktadır. Çocukluk dönemi içerisinde 0 - 6 yaşı kapsayan "okul öncesi dönemi” gelişim sürecinin en hızlı dönemlerinden biridir (Oktay, 2007). Gelișimin, en hızlı olduğu okul öncesi dönemde üstün yetenekli çocukların ilgi ve yeteneklerine uygun zengin uyarıcı çevre, ev ortamlarının düzenlenmesi, eğitim programlarının hazırlanması, ailelerin ve öğretmenlerin bilgilendirilmesi ve bilinçlendirmesi onların bilişsel, fiziksel, sosyal ve duygusal gelișim alanlarını ulaşabileceği en üst seviyeye çıkarılması açısından oldukça önemlidir (Dağlıŏlu, 2010). Üstün yetenekli çocukların, erken dönemde belirlenmesinde ve yeteneklerinin geliştirilmesinde okul öncesi dönem büyük önem taşımaktadır. Okul öncesi dönemde üstün ve özel yetenekli çocukların aileleri, erken müdahalede önemli bir yere sahiptir. Anne-babalar çocukların ilk eğitimcileridir ve çocukların yeteneklerini geliştirebilirler. $\mathrm{Bu}$ nedenle aile, eğitimci ve öğretmenlerin üstün yetenekli çocukların yeteneklerini erken yıllarda fark edebilmesi ve gerçek performanslarını ortaya çıkarabilmeleri açısından uygun ortamlar sağlamaları gerekmektedir (Dönmez ve Kurt, 2004). Erken çocuklukta, üstün yeteneklilik özelliği gösteren çocukların ilk y1llarda gösterdiği belirtileri; akranlarından büyük çocukların ilgi duyduğu (savaş, doğa olayları, açlık vb.) konularla ilgilenme, güçlü yaratıcılık ve bellek, yaşının üstünde bulmaca çözme, puzzle ve oyuncaklarla ilgilenme, mükemmeliyetçi davranış ve kişilik geliştirme, yaşıtlarından erken okuma-yazma becerisi kazanma, erkenden matematik (sayı ve sembolleri) becerisi geliştirme, erken dil-konuşma gelişimi, yüksek düzeyde merak ve araştırmacı olma, uzun süre odaklanma ve keskin gözlem yapabilme şeklinde sıralamak mümkündür (Metin, 2015).

Üstün yetenekli öğrenciler; zihinsel ya da kendi yetenek alanlarında akranlarına göre normalin üstünde gelişim gösteren, meraklı (Blackburn \& Erickson, 1986), yaratıcı (Torrance, \& Goff, 1989), esnek düşünebilen (VanTassel-Baska, 2005), hızlı öğrenebilen (Wright, 2008), hayal güçleri oldukça geniş (Kaufman, Plucker \& Russell, 2012), mükemmel bir düzeyde sorun çözme becerilerine sahip olan (Sak, 2014), sorgulayıcı öğrenme yaklaşımlarını geliştiren (Rogers, 2009) bireylerdir. Üstün yetenekli bireylerin yeteneklerinin geliştirilmesi ancak düzenli ve sistemli bir eğitimle mümkündür. Toplum için önemli bir değere sahip ve sınırlı sayıda olan bu bireylerin, toplum içinde kaybolmaması adına yeteneklerine uygun, verimli bir eğitim hayatı için duyulan ortam ve imkânların sağlanması gerekmektedir (Çapan, 2010). Toplumu oluşturan bireylerin ortalama 5'lik bölümün \% 2'lik k1smı üstün zekâlı bireylerden, \% 3'lük kısmı ise alt zekâ grubu bireyler oluşturmaktadır (MEB, 2010). \%2'lik kısımda olan üstün yetenekli bireylerin erken dönemde fark edilerek, yetenekleri doğrultusunda eğitim almaları, toplumda yaşanılan olaylara yön verecek olan bireylerin gelişmesini sağlayacaktır. Bireysel farklılıklar dikkate alınarak düzenlenmiş bir eğitim-öğretim programı tartışmasız bireyin topluma uyumlu, mutlu ve faydalı bir birey olmasına aynı zamanda da toplumun gelişmişlik düzeyine katkı sağlamasına olanak tanır (Bozgeyikli, Doğan, Işıklar, 2010). Gelişimin, tarihi incelendiğinde yüzyıllar boyunca toplumlara yön verenlerin, hatta bir devri kapatıp bir devri açanların "pasif çoğunluk" değil; "aktif azınlık" diye tanımlanan ve üretkenlik, verimlilik, liderlik gibi özellikleri bulunan "üstün ya da özel yetenekli kişiler” olduğu bilinmektedir (Uzun, 2004).

Üstün yetenekli öğrencilerin, potansiyellerin farkına varılması, kişisel gelişimleri, bütünleşme ve üreten bir birey olabilmeleri için eğitim ve gelişim ihtiyaçlarının sağlıklı bir şekilde karşılanması toplumların gelişimi açısından önem verilmesi gerekmektedir (Burger, 2006). Toplumun farklı sosyo-ekonomik tabakalarında ve kültürel farklılıklarla birlikte üstün yetenekli çocuklara rastlamak mümkündür (Gökdere \& Küçük, 2003). Bu anlamda üstün yetenekli çocukların eğitiminde programların çok yönlü ve yaratıcı özellikler taşıması, aynı zamanda eğitimlerinin bu bireylerin özellik ve gereksinimlerine göre farklılaştırılması gerekmektedir (Baykoç, 2014; Kontaş, 2010; Palanc1, 2004). Özellikle okul öncesi dönemden başlayarak üstün yetenekli öğrencilerin eğitimlerinin farklılaştırılmasının gerektiği vurgulanmaktadır. (Coşar, Çetinkaya \& Çetinkaya, 2015). Üstün yeteneklilerin eğitimi alanında otorite olarak görülen araştırmacılar, öğretmenlerin üstün yetenekli öğrencilerin eğitim ihtiyaçlarını karşılamak için bu öğrencilerin bireysel özelliklerini bilmesi ve eğitim-öğretimin farklılaştırılması açısından yeterli eğitim alması gerektiğini savunmaktadırlar (Levent, 2011).

Üstün yetenekli öğrencilere eğitim verecek olan öğretmenler; normalin üzerinde zekâya sahip, esprili, mizahi yönü olan, heyecanlı, esnek, çalışkan, kendine son derece güvenen, araştırmacı, güncel bilgileri takip eden, yeni fikirlere açık, doğaya ve çevreye duyarlı bir kişiliğe sahip olmalıdır. Öğretmenlerin zorlayıcı, baskıcı ve otoriter olmayan, işbirlikçi, demokratik, öğrencilerine ipucu ve geri bildirim veren, deneyimli, öğrencileri tüm yönleri ile tanıyan, gereksinimlerine cevap veren, onları takdir eden ve alan bilgisinde yeterli olma gibi mesleki özelliklere de sahip olmaları gerektiği bildirilmektedir (Croft, 2003; Çepni, Gökdere ve Küçük, 2002; Metin, 1999; Metin ve Dağlıoğlu, 2014; Ravenna, 2008; Roger, 2009; Sak, 2009; Sisk, 1987; Tischler \& Vialle, 2009). Ataman (1998), öğretmenlerin üstün zekâlı çocukların tanılanması aşamasında yeterince başarı gösteremediklerini, öğretmenlere verilecek olan bazı ipuçları sayesinde bu konudaki yeterliliklerini artırmanın söz konusu olduğunu belirtmiştir. Üstün zekâlı çocuklara öğretmenlik yapacak 
kişilerde olması gereken bazı yeterlilikler konusunda birçok araştırmalar yapılmış ve bu araştırmalar sonucunda ortaya çıkan en belirgin özelliklerini; a) öğrenmeye ilgisi ve yeterli olma, b) adil ve tarafsı davranma, c) esnek olma, d) öğretimde yeni yöntemler ve yeterliliklere sahip olma, e) işbirlikçi ve demokratik olma, f) esprili, g) sorunlara çözüm bulabilen, h) ilgi alanında geniş bir yelpazeye sahip olan, i) ödüllendirme ve takdir etme becerisi olan, j) güler yüzlü, dış görünüşüne itina eden şeklinde belirtmiştir. Üstün yetenekli çocuklara eğitim verme konusunda eğitim düzeyi yeterli olmayan öğretmenler, bu özellikteki öğrencilerin ihtiyaçlarına cevap vermede istenilen nitelikte olmadıkları belirtilmiştir. Bununla beraber öğretmenlerin hizmet öncesinde aldıkları lisans eğitiminde de üstün yeteneklilik hakkında gerekli altyapı bilgisi de verilmemektedir (Levent, 2011).

Erken çocuklukta, üstün yeteneklilik özelliği gösteren çocukların ilk yıllarda gösterdiği belirtileri; akranlarından büyük çocukların ilgi duyduğu (savaş, doğa olayları, açlık vb.) konularla ilgilenme, güçlü yaratıcılık ve bellek, yaşının üstünde bulmaca çözme, puzzle ve oyuncaklarla ilgilenme, mükemmeliyetçi davranış ve kişilik geliştirme, yaşıtlarından erken okuma-yazma becerisi kazanma, erkenden matematik (sayı ve sembolleri) becerisi geliştirme, erken dil-konuşma gelişimi, yüksek düzeyde merak ve araştırmacı olma, uzun süre odaklanma ve keskin gözlem yapabilme şeklinde sıralamak mümkündür (Metin, 2015). Bu anlamda üstün yetenekli çocukların eğitiminde programların çok yönlü ve yaratıcı özellikler taşıması, aynı zamanda eğitimlerinin bu bireylerin özellik ve gereksinimlerine göre farklılaştırılması gerekmektedir (Baykoç, 2014; Kontaş, 2010; Palanc1, 2004). Özellikle okul öncesi dönemden başlayarak üstün yetenekli öğrencilerin eğitimlerinin farklılaştırılmasının gerektiği vurgulanmaktadır. (Coşar, Çetinkaya \& Çetinkaya, 2015). Üstün yeteneklilerin eğitimi alanında otorite olarak görülen araştırmacılar, öğretmenlerin üstün yetenekli öğrencilerin eğitim ihtiyaçlarını karşılamak için bu öğrencilerin bireysel özelliklerini bilmesi ve eğitim-öğretimin farklılaştırılması açısından yeterli eğitim alması gerektiğini savunmaktadırlar (Levent, 2011). Üstün yetenekli çocuklara eğitim verme konusunda eğitim düzeyi yeterli olmayan öğretmenler, bu özellikteki öğrencilerin ihtiyaçlarına cevap vermede istenilen nitelikte olmadıkları belirtilmiştir. Bununla beraber öğretmenlerin hizmet öncesinde aldıkları lisans eğitiminde de üstün yeteneklilik hakkında gerekli altyapı bilgisi de verilmemektedir (Levent, 2011).

Ülkelerin kaderine yön verecek, toplumu olumlu yönde etkileyecek potansiyele sahip olan bireyler doğru bir şekilde, uygun yöntemlerle belirlenmediğinde ve eğitim ortamları oluşturulmadığında, toplumları büyük sorunlar çıkarabilecek bireylere dönüşme tehlikesi ile karşı karşıya bırakabilmektedir (Sak, 2014). Üstün yetenekli ve üstün zekâlı çocuklar için olanakların sınırlı olması nedeniyle akranları ile aynı eğitimi almak zorunda kalmaktadırlar. Öğrenim alanlarının öğrencinin ilgi, istek ve yeteneklerini daha üst seviyelere çıkaracak şekilde ve kendini geliştirecek şekilde düzenlenmesi önem taşımaktadır (Baykoç, 2014). Bu gereklilikleri yerine getirecek kişiler olan öğretmenlerin üstün yetenekli öğrencilere yönelik algı ve eğitim ihtiyaçlarının belirlenmesi de önem taşımaktadır. Dünya'da teknoloji çok hızlı bir değişim göstermeye devam ederken, toplumlarda yönetim süreçleri farklılaşma yönünde ilerlemektedir. Bu bağlamda değişimlerin hedefinde bilim ve teknolojinin odaklandığ bilgi yer almaktadır. Toplumların tüm bu değişimlere yetişebilmesi adına yetenekli bireylerinden beklentileri de önem kazanmaktadır.

Bu değişimler ve gelişmeler yönünde, Kuzey Kıbrıs Türk toplumunun da hak ettiği yer edinebilmesi kaliteli eğitim, insan kaynaklarına yapılan yatırım ve sosyal alt yapı hizmet sunumlarının iyileştirilmesi ile mümkündür. Bunu sağlamak için, Kıbrıs Türk toplumunun her bireyine hem örgün hem de yaygın eğitim kurumlarında "yaşam boyu öğrenme" yi temele alan yaklaşımla; dünya piyasaları ile rekabet ortamına uyum, zekâ işlevlerini geliştiren, araştırmacı ve yaratıcı düşünceye odaklanan bir eğitim sisteminin uygulanmasıyla gerçekleşecektir (KKTC Eğitim Sistemi, 2005). Alan yazın araştırmaları incelendiğinde, Kuzey Kıbrıs Türk Cumhuriyeti’nde (KKTC) üstün yetenekli öğrenciler ile ilgili sınırlı sayıda çalışmalara rastlanmıştır. Özellikle normal eğitim sistemi içerisinde süreklilik gösteren bu öğrencileri erken yaşta belirlemek, onlar için uygun eğitim ortamları oluşturmak, potansiyellerini geliştirmek adına her yönüyle öğretmenler kendini geliştirmelidir. Bu anlamda, Kuzey Kıbrıs'ta okul öncesi öğretmenlerinin üstün yetenekli çocuklar hakkında algıları ve eğitim ihtiyaçlarına yönelik çalışmalar gerçekleştirilememesi, bu okullarda görevli öğretmenlerin üstün yetenekli öğrenciler konusuna yönelik araştırmalara ihtiyaç duyduğunu göstermektedir. Üstün yetenekli çocukların, tıpkı özel gereksinimli olan akranları gibi okul öncesi dönemde eğitim almaları, var olan yeteneklerini en üst seviyeye kadar çıkartmaları açısından önem taşımaktadır. Ülkemizde, çocuk yetiştirme ile ilgili ailelerin bilgi ve eğitim seviyesi, eğitim firsatlarını yaratma adına gerekli ekonomik koşullar gibi etkenler dikkate alındığında okul öncesi eğitimi özellikle bu çocuklar için alınması gereken eğitimlerden biridir (Ataman, 2011).

Üstün yetenekli çocukların erken yaşta belirlenmesi ve yetenekleri doğrultusunda geliştirilmesi için okul öncesi öğretmenlerinin bilgi birikimlerinin önemi yadsınamaz bir gerçektir. Bu araştırmada okul öncesi öğretmenlerinin üstün yetenekli öğrencilere yönelik algı ve eğitim ihtiyaçlarının belirlenmesi amaçlanmıştır. Bu amaca ulaşmak için aşağıdaki sorulara cevap aranmıştır.

1. Okul öncesi öğretmenlerinin üstün yetenekli çocuklara yönelik algıları genel olarak nasıldır?

| Kastamonu Eğitim Dergisi, 27(5), 2019| 
2. Okul öncesi öğretmenlerinin üstün yetenekli çocuklara yönelik algıları,

2.1. Yaşa,

2.2. Mesleki kıdeme,

2.3. Üstün yetenekli çocuklar için daha önce eğitim almalarına,

2.4. Üstün yetenekli çocuklar ile ilgili kaynaklara nereden ulaştkları değişkenlerine göre anlamlı bir farklılık göstermekte midir?

3. Okul Öncesi öğretmenlerin üstün yetenekli öğrencilere yönelik eğitim genel olarak ihtiyaçları nasıldır?

\section{Yöntem}

Bu araştırmada okul öncesi öğretmenlerinin üstün yetenekli öğrencilere yönelik algı ve eğitim ihtiyaçlarını belirlemek amacıyla, evren hakkında genel bir yargıya varma olanağı sağlayan modellerden genel tarama (survey) modeli kullanılmıştır. Genel tarama modeli, çok sayıda elemandan oluşan bir evrende, evren hakkında genel bir yargıya varmak amacı ile evrenin tümü ya da ondan alınacak bir grup örnek ya da örneklem üzerinde yapılan tarama düzenlemelerdir (Karasar, 2005).

\section{Çalışma Grubu}

Bu araştırmanın evrenini Kuzey Kıbrıs Türk Cumhuriyeti Milli Eğitim ve Kültür Bakanlığı, İlköğretim kademesinde olan 99 ilköğretim okulu bünyesinde ve 13 anaokulunda görev yapan okul öncesi öğretmenleri oluşturmuştur. Evreni oluşturan öğretmen sayısına ilişki veriler KKTC Milli Eğitim ve Kültür Bakanlığı, İlköğretim Dairesi Müdürlüğü istatistik verilerinden alınan bilgiler doğrultusunda toplanmıştı. KKTC'de bulunan ilköğretim kademesinde, ilköğretim okulları içerisinde ve bağımsız resmi kurum olan anaokullarında görev yapan 112 okul öncesi öğretmeni bu çalışmanın evrenini oluşturmuştur. Büyüköztürk ve arkadaşları (2008), evreni "Araştırma sorularını cevaplamak için gerekli olan verilerin (ölçümlerin) elde edildiği canlı ya da cansız varlıklardan oluşan büyük bir grup" olarak açıklamaktadır. Araştırmanın başlangıcında planlanan şekilde 112 öğretmene bilgi formu, ölçek ve anket dağıtılmasına rağmen, 104 ölçek geri gelmiştir. Ölçeğin hatalı ya da eksik doldurulması, doldurmak istenmemesi gibi nedenlerden dolayı uygulama 100 okul öncesi öğretmeni ile gerçekleştirilmiş ve bu öğretmenlerden 91'i bayan 9'u erkek öğretmenden oluşmuştur ve toplamda 12 öğretmen evren dışı kalmıştr.

\section{Veri Toplama Araçları}

Araşttrmada verileri elde etmek amacıyla gerekli olan veri toplama araçları olarak üç bilgi toplama aracına yer verilmiştir. Demirok ve Özcan (2016) tarafindan geliştirilen öğretmenlerin üstün yetenekli öğrencilere yönelik algılarını belirlemek için kullanılan Üstün Yetenekli Öğrencilere Yönelik Algı Ölçeği ve Demirok (2012), tarafindan geliştirilen Üstün Yetenekli Öğrencilere Yönelik Eğitim İhtiyaçlarını Belirleme Anketi veri toplama araçları olarak kullanıımıştır. Araştırmacı, kullanılan veri toplama araçlarının, içerik geçerliliğini kontrol etmek için uzman görüşlerine başvurarak geçerlilik ve güvenirliliğin 15 uzman görüşü ile yeterli olduğunu belirtmiştir. Araştırmada kullanılan "Üstün Yetenekli Öğrencilere Yönelik Algı Ölçeği beş boyuttan ve 34 maddeden oluşmaktadır. Üstün Yetenekli Öğrencilere Yönelik Algı Ölçeğindeki boyutlar, "Öğrenme İstekliliği”, "ifade Etme Özellikleri”, "Kişisel Özellikleri”, "Öğrenme Özellikleri”, ve "Zihinsel Özellikleri" şeklindedir. Araştırmada likert tipi olarak hazırlanmış ölçekte yer alan her bir madde için; "Kesinlikle katılmıyorum, Katılmıyorum, Kararsızım, Katılıyorum, Kesinlikle Katılıyorum" gibi beş kategoriden biriyle cevap alınmıştır. Araştırmada kullanılan "Üstün Yetenekli Öğrencilere Yönelik Eğitim ihtiyaçlarını belirleme" anketi 25 maddeden oluşmuş ve "Hiç ihtiyaç Hissetmiyorum, Az İhtiyaç Hissediyorum ve Çok intiyaç Hissediyorum" şeklinde üçlü likert tipi anket doğrultusunda cevaplar alınmıştr.

\section{Verilerin Analizi}

Araştırmada elde edilen veriler istatistik uzmanlarının görüşleri dikkate alınarak uygun istatiksel teknikler kullanılarak analiz edilmiştir. Ayrıca analiz edilen veriler, tablolar oluşturularak açıklanmış ve yorumlanmıştır. Araştırmada, üstün yetenekli öğrencilere yönelik algı ölçeği ve öğretmenlerin üstün yetenekli öğrenciler ile ilgili eğitim ihtiyaçlarına ilişkin görüşleri'nden elde edilen veriler SPSS 23.0 paket programı kullanılarak analiz edilmiştir. Araştırmanın, demografik bilgileri açıklanırken, frekans ve yüzdelik dağılımlar kullanılmış ve yorumlanmıştır. Üstün yeteneklilere ilişkin algı ve eğiğim intiyaçlarının belirlenmesinin alt faktörlerini açıklarken ise aritmetik ortalama $(\bar{X})$, standart sapma (S), en düşük ve en yüksek değerler kullanılmıştır. Araştırmada okul öncesi öğretmenlerinin demografik özelliklerinin farklılıklarına göre üstün yeteneklilere ilişkin yönelik algı ölçeğinden elde edilen veriler normal dağıım halinde parametrik testlerden olan t-testi kullanılarak analiz edilmiş ve tablo şeklinde açıklanmıştı. Elde edilen veriler normal dağılım göstermediği durumlarda ise parametrik olmayan testlerden Mann-Whitney $U$ ve Kruskal Wallis Testi kullanılmıştır. ANOVA testi sonrasında 
farklılıkları belirlemek için tamamlayıcı post-hoc analizi olarak Scheffe testi kullanılmıştır. Analiz verileri tablo haline getirilmiş ve yorumlanarak sonuçlara ulaşılmıştır. Grupların birbirleriyle olan ilişkilerinin ya da ortalamalar arasındaki farkların anlamlılık testinde 0.05 düzeyi esas alınmıştır.

\section{Bulgular}

Okul öncesi öğretmenlerinin üstün yetenekli öğrencilere yönelik algılarının betimsel istatistik sonuçları Tablo 1'de verilmiştir.

Tablo 1. Okul Öncesi Öğretmenlerinin Üstün Yetenekli Öğrencilere Yönelik Algılarının Betimsel İstatistik Sonuçları

\begin{tabular}{lccccc}
\hline Boyut & N & Min. & Mak. & $\bar{X}$ & S \\
\hline Öğrenme İstekliliği & 100 & 2.56 & 4.89 & 4.17 & 0.46 \\
Ifade Etme Özellikleri & 100 & 2.78 & 4.78 & 4.14 & 0.41 \\
Kişilik Özellikleri & 100 & 3.5 & 4.5 & 4.03 & 0.26 \\
Zihinsel Özellikleri & 100 & 3 & 5 & 4.47 & 0.56 \\
Öğrenme Özellikleri & 100 & 3.17 & 5 & 4.17 & 0.43 \\
Genel Ortalama & 100 & 2.97 & 4.76 & 4.17 & 0.37 \\
\hline
\end{tabular}

Tablo 1'de görüldüğü gibi okul öncesi öğretmenlerinin üstün yetenekli öğrencilere yönelik algılarının ortalama puanı "katılıyorum" ( $\bar{X}=4.17, S=.37$ ) sınırları içerisinde belirlenmiştir. Bu bulgu, okul öncesi öğretmenlerinin üstün yetenekli öğrencilere yönelik algılarının olumlu yönde olduğu şeklinde yorumlanabilir.

\section{Okul Öncesi Öğretmenlerinin Üstün Yetenekli Öğrencilere Yönelik Algılarının Yaşlarına Göre Karşılaştırılması}

Okul öncesi öğretmenlerinin üstün yetenekli öğrencilere yönelik algılarının yaşlarına göre anlamlı bir şekilde farklılaşıp farklılaşmadığını belirlemek için One Way ANOVA yapılmıştır. Tablo 2'de okul öncesi öğretmenlerinin üstün yetenekli öğrencilere yönelik algılarıyla ilgili betimsel veriler yaşlarına göre verilmiştir.

Tablo 2. Okul öncesi öğretmenlerinin üstün yetenekli öğrencilere yönelik algı genel ortalama puanlarının yaşlarına göre karşılaştırılması

\begin{tabular}{|c|c|c|c|c|c|c|c|c|}
\hline Boyut & Yaş & N & $\bar{X}$ & S & df & $\mathbf{F}$ & p & Açıklama \\
\hline \multirow{4}{*}{ Öğrenme İstekliliği } & $20-30$ & 49 & 4.36 & 0.32 & \multirow{4}{*}{2} & \multirow{4}{*}{9.592} & \multirow{4}{*}{.000} & \multirow{4}{*}{$\begin{array}{l}\mathrm{p}<0.05 \\
\text { Fark anlamlı }\end{array}$} \\
\hline & $31-40$ & 35 & 3.94 & 0.60 & & & & \\
\hline & 41 ve üstü & 16 & 4.13 & 0.19 & & & & \\
\hline & Total & 100 & 4.17 & 0.46 & & & & \\
\hline \multirow{4}{*}{ İfade Etme Özellikleri } & $20-30$ & 49 & 4.33 & 0.22 & \multirow{4}{*}{2} & \multirow{4}{*}{13.386} & \multirow{4}{*}{.000} & \multirow{4}{*}{$\begin{array}{l}\mathrm{p}<0.05 \\
\text { Fark anlamlı }\end{array}$} \\
\hline & $31-40$ & 35 & 4.00 & 0.55 & & & & \\
\hline & 41 ve üstü & 16 & 3.88 & 0.10 & & & & \\
\hline & Total & 100 & 4.14 & 0.41 & & & & \\
\hline \multirow{4}{*}{ Kişilik Özellikleri } & $20-30$ & 49 & 4.04 & 0.18 & \multirow{4}{*}{2} & \multirow{4}{*}{.871} & \multirow{4}{*}{.422} & \multirow{4}{*}{$\begin{array}{l}\mathrm{p}>0.05 \\
\text { Fark anlam- } \\
\mathrm{sIz}\end{array}$} \\
\hline & $31-40$ & 35 & 3.99 & 0.26 & & & & \\
\hline & 41 ve üstü & 16 & 4.08 & 0.43 & & & & \\
\hline & Total & 100 & 4.03 & 0.26 & & & & \\
\hline \multirow{4}{*}{ Zihinsel Özellikleri } & $20-30$ & 49 & 4.74 & 0.25 & \multirow{4}{*}{2} & \multirow{4}{*}{15.395} & \multirow{4}{*}{.000} & \multirow{4}{*}{$\begin{array}{l}\mathrm{p}<0.05 \\
\text { Fark anlamlı }\end{array}$} \\
\hline & $31-40$ & 35 & 4.25 & 0.63 & & & & \\
\hline & 41 ve üstü & 16 & 4.11 & 0.69 & & & & \\
\hline & Total & 100 & 4.47 & 0.56 & & & & \\
\hline \multirow{4}{*}{ Öğrenme Özellikleri } & $20-30$ & 49 & 4.29 & 0.42 & \multirow{4}{*}{2} & \multirow{4}{*}{4.921} & \multirow{4}{*}{.009} & \multirow{4}{*}{$\begin{array}{l}\mathrm{p}<0.05 \\
\text { Fark anlamlı }\end{array}$} \\
\hline & $31-40$ & 35 & 4.00 & 0.47 & & & & \\
\hline & 41 ve üstü & 16 & 4.18 & 0.28 & & & & \\
\hline & Toplam & 100 & 4.17 & 0.43 & & & & \\
\hline
\end{tabular}

| Kastamonu Eğitim Dergisi, 27(5), 2019 | 


\begin{tabular}{|c|c|c|c|c|c|c|c|c|}
\hline Boyut & Yaş & $\mathbf{N}$ & $\bar{X}$ & $\mathbf{S}$ & df & $\mathbf{F}$ & p & Açıklama \\
\hline \multirow{4}{*}{ Genel Puan } & $20-30$ & 49 & 4.33 & 0.23 & \multirow{4}{*}{2} & \multirow{4}{*}{9.914} & \multirow{4}{*}{.000} & \multirow{4}{*}{$\begin{array}{l}\mathrm{p}<0.05 \\
\text { Fark anlamlı }\end{array}$} \\
\hline & $31-40$ & 35 & 4.01 & 0.48 & & & & \\
\hline & 41 ve üstü & 16 & 4.06 & 0.22 & & & & \\
\hline & Total & 100 & 4.17 & 0.37 & & & & \\
\hline
\end{tabular}

Tablo 2'de görüldüğü gibi, öğretmenlerin üstün yetenekli öğrencilerin 'öğrenme istekliliği' boyutundaki algıları arasında yaşlarına göre anlamlı bir farklılık bulunmuştur $(F=9.592, p<0.05)$. Scheffe testi sonucu 20-30 yaş grubu öğretmenlerin algılarının 31-40 yaş grubu öğretmenlerden anlamlı derecede yüksek olduğu bulunmuştur.

Okul öncesi öğretmenlerinin üstün yetenekli öğrencilerin 'ifade etme özellikleri' boyutundaki algıları arasında da yaşlarına göre anlamlı bir farklılık bulunmuştur ( $F=13.386, p<0.05)$. Scheffe testi sonucu 20-30 yaş grubu öğretmenlerin algılarının 31-40 yaş grubu ve 41 ve üstü yaş grubu öğretmenlerden anlamlı derecede yüksek olduğu bulunmuştur.

Okul öncesi öğretmenlerinin üstün yetenekli öğrencilerin 'kişilik özelliklerine' yönelik algıları arasında yaşlarına göre anlamlı bir farklııık bulunmamıştır ( $F=8.771, p>0.05)$.

Okul öncesi öğretmenlerinin üstün yetenekli öğrencilerin 'zihinsel özellikleri' boyutundaki algıları arasında yaşlarına göre anlamlı bir farklılık bulunmuştur $(F=15.395, p<0.05)$. Scheffe testi sonucu 20-30 yaş grubu öğretmenlerin algılarının 31-40 yaş grubu ve 41 ve üstü yaş grubu öğretmenlerden anlamlı derecede yüksek olduğu bulunmuştur.

Okul öncesi öğretmenlerinin üstün yetenekli öğrencilerin 'öğrenme özellikleri' boyutundaki algıları arasında da yaşlarına göre anlamlı bir farklılık bulunmuştur $(\mathrm{F}=4.921, \mathrm{p}<0.05)$. Scheffe testi sonucu 20-30 yaş grubu öğretmenlerin algılarının, 31-40 yaş grubu öğretmenlerden anlamlı derecede yüksek olduğu bulunmuştur.

Genel olarak okul öncesi öğretmenlerin üstün yetenekli öğrencilere yönelik algıları arasında da yaşlarına göre anlamlı bir farklılık bulunmuştur ( $\mathrm{F}=9.914, \mathrm{p}<0.05)$. Scheffe testi sonucu 20-30 yaş grubu öğretmenlerin algılarının, 31-40 yaş grubu öğretmenlerden anlamlı derecede yüksek olduğu bulunmuştur.

Okul Öncesi Öğretmenlerinin Üstün Yetenekli Öğrencilere Yönelik Algılarının Mesleki Kıdemlerine Göre Karşılaştırılması

Okul öncesi öğretmenlerinin üstün yetenekli öğrencilere yönelik algılarının mesleki kıdemlerine göre anlamlı bir şekilde farklılaşıp farklılaşmadığını belirlemek için One Way ANOVA yapılmıştır. Tablo 3'te öğretmenlerin yaşlarına göre üstün yetenekli öğrencilere yönelik algılarıyla ilgili betimsel veriler verilmiştir.

Tablo 3. Okul Öncesi Öğretmenlerinin Üstün Yetenekli Öğrencilere Yönelik Algı Genel Ortalama Mesleki Kıdemlerine Göre Puanlarının Karşılaştırılması

\begin{tabular}{llccccccc}
\hline Boyut & & $\mathbf{N}$ & $\bar{X}$ & $\mathbf{S}$ & $\mathbf{d f}$ & $\mathbf{F}$ & $\mathbf{p}$ & Açıklama \\
\hline \multirow{3}{*}{ Öğreme İstekliliği } & $1-5$ yıl & 21 & 4.44 & 0.39 & & & & \\
& $6-10$ yıl & 12 & 4.47 & 0.25 & & & & \\
& $11-15$ yıl & 35 & 4.13 & 0.06 & & & & p<0.05 \\
& $16-20$ yıl & 19 & 3.80 & 0.80 & 4 & 8.047 & .000 & Fark anlamlı \\
& 21 yıl ve üzeri & 13 & 4.14 & 0.21 & & & & \\
& Total & 100 & 4.17 & 0.46 & & & & \\
Iffade Etme Özellikleri & $1-5$ yıl & 21 & 4.30 & 0.23 & & & & \\
& $6-10$ yıl & 12 & 4.56 & 0.00 & & & & \\
& $11-15$ yıl & 35 & 4.15 & 0.13 & & & & p<0.05 \\
& $16-20$ yıl & 19 & 3.89 & 0.74 & & & & \\
& 21 yıl ve üzeri & 13 & 3.85 & 0.06 & & & & \\
& Total & 100 & 4.14 & 0.41 & & & & \\
\hline
\end{tabular}




\begin{tabular}{|c|c|c|c|c|c|c|c|c|}
\hline Boyut & & $\mathbf{N}$ & $\bar{X}$ & $\mathbf{S}$ & df & $\mathbf{F}$ & $\mathbf{p}$ & Açıklama \\
\hline \multirow{3}{*}{ Kişilik Özellikleri } & $1-5 \mathrm{yll}$ & 21 & 3.93 & 0.08 & \multirow{6}{*}{4} & \multirow{6}{*}{2.538} & \multirow{6}{*}{.045} & \multirow{6}{*}{$\begin{array}{c}\mathrm{p}<0.05 \\
\text { Fark anlamlı }\end{array}$} \\
\hline & 6-10 yıl & 12 & 4.21 & 0.23 & & & & \\
\hline & 11-15 yıl & 35 & 4.03 & 0.09 & & & & \\
\hline \multirow{9}{*}{ Zihinsel Özellikleri } & $16-20$ yıl & 19 & 3.99 & 0.36 & & & & \\
\hline & 21 yıl ve üzeri & 13 & 4.08 & 0.48 & & & & \\
\hline & Total & 100 & 4.03 & 0.26 & & & & \\
\hline & 1-5 yıl & 21 & 4.71 & 0.25 & \multirow{6}{*}{4} & \multirow{6}{*}{15.843} & \multirow{6}{*}{.000} & \multirow{6}{*}{$\begin{array}{c}\quad \mathrm{p}<0.05 \\
\text { Fark anlamlı }\end{array}$} \\
\hline & 6-10 yıl & 12 & 5.00 & 0.00 & & & & \\
\hline & 11-15 yıl & 35 & 4.54 & 0.14 & & & & \\
\hline & $16-20$ yıl & 19 & 3.86 & 0.83 & & & & \\
\hline & 21 yıl ve üzeri & 13 & 4.29 & 0.59 & & & & \\
\hline & Total & 100 & 4.47 & 0.56 & & & & \\
\hline \multirow{3}{*}{ Öğrenme Özellikleri } & $1-5 \mathrm{yll}$ & 21 & 4.43 & 0.51 & \multirow{6}{*}{4} & \multirow{6}{*}{4.894} & \multirow{6}{*}{.001} & \multirow{6}{*}{$\begin{array}{c}\mathrm{p}<0.05 \\
\text { Fark anlamlı }\end{array}$} \\
\hline & 6-10 yıl & 12 & 4.38 & 0.38 & & & & \\
\hline & $11-15$ yıl & 35 & 4.01 & 0.05 & & & & \\
\hline \multirow{9}{*}{ Genel Puan } & $16-20$ yıl & 19 & 4.02 & 0.65 & & & & \\
\hline & 21 yıl ve üzeri & 13 & 4.18 & 0.29 & & & & \\
\hline & Total & 100 & 4.17 & 0.43 & & & & \\
\hline & $1-5 \mathrm{yll}$ & 21 & 4.34 & 0.27 & \multirow{6}{*}{4} & \multirow{6}{*}{8.029} & \multirow{6}{*}{.000} & \multirow{6}{*}{$\begin{array}{c}\quad \mathrm{p}<0.05 \\
\text { Fark anlamlı }\end{array}$} \\
\hline & 6-10 yıl & 12 & 4.49 & 0.09 & & & & \\
\hline & 11-15 yıl & 35 & 4.15 & 0.09 & & & & \\
\hline & $16-20$ yıl & 19 & 3.90 & 0.65 & & & & \\
\hline & 21 yıl ve üzeri & 13 & 4.07 & 0.24 & & & & \\
\hline & Total & 100 & 4.17 & 0.37 & & & & \\
\hline
\end{tabular}

Tablo 3'te görüldüğü gibi, okul öncesi öğretmenlerinin üstün yetenekli öğrencilerin 'öğrenme istekliliği' boyutundaki algıları arasında mesleki kıdemlerine göre anlamlı bir farklılık bulunmuştur $(F=8.047, p<0,05)$. Scheffe testi sonucu 1620 yıl kıdeme sahip öğretmenlerin algılarının, 1-5 yıl ve 6-10 yıl kıdeme sahip öğretmenlerden anlamlı derecede düşük olduğu bulunmuştur.Okul öncesi öğretmenlerinin üstün yetenekli öğrencilerin 'ifade etme özellikleri' boyutundaki algıları arasında da mesleki kıdemlerine göre anlamlı bir farklılık bulunmuştur ( $F=10.324, p<0.05)$. Scheffe testi sonucu 6-10 yıl kıdeme sahip öğretmenlerin algılarının, 11-15 yıl, 16-20 yıl ve 21 yıl ve üzeri kıdeme sahip öğretmenlerden anlamlı derecede yüksek olduğu, 1-5 yıl kıdeme sahip öğretmenlerin algılarının, 16-20 yıl ve 21 yıl ve üzeri kıdeme sahip öğretmenlerden anlamlı derecede yüksek olduğu bulunmuştur.

Okul öncesi öğretmenlerinin üstün yetenekli öğrencilerin 'kişilik özellikleri' boyutundaki algıları arasında da mesleki kıdemlerine göre anlamlı bir farklılık bulunmuştur $(F=2.538, p<0.05) .6$ ve10 yıl mesleki kıdeme sahip öğretmenlerin algılarının diğer öğretmenlerden daha yüksek olduğu görülmektedir.

Okul öncesi öğretmenlerinin üstün yetenekli öğrencilerin 'zihinsel özellikleri' boyutundaki algıları arasında da mesleki kıdemlerine göre anlamlı bir farklılık bulunmuştur ( $F=15.843, p<0.05)$. Scheffe testi sonucu 16-20 yıl kıdeme sahip öğretmenlerin 1-5 yıl, 6-10 yıl ve 11-15 yıl kıdeme sahip öğretmenlerden anlamlı derecede düşük olduğu, 6-10 yıl kıdeme sahip öğretmenlerin algılarının, 21 yıl ve üzeri kıdeme sahip olan öğretmenlerden anlamlı derecede yüksek olduğu bulunmuştur.

Okul öncesi öğretmenlerinin üstün yetenekli öğrencilerin 'öğrenme özellikleri' boyutundaki algıları arasında da mesleki kıdemlerine göre anlamlı bir farklılık bulunmuştur $(F=4.894, p<0.05)$. Scheffe testi sonucu 1-5 yıl kıdeme sahip öğretmenlerin algılarının 11-15 yıl ve 16-20 yıl kıdeme sahip olan öğretmenlerden anlamlı derecede yüksek olduğu bulunmuştur.

Genel olarak okul öncesi öğretmenlerinin üstün yetenekli öğrencilere yönelik algıları arasında da mesleki kıdemlerine göre anlamlı bir farklılık bulunmuştur $(F=8.029, p<0.05)$. Scheffe testi sonucu 6-10 yıl kıdeme sahip öğretmenlerin algılarının, 11-15 yıl, 16-20 yıl ve 21 yıl ve üzeri kıdeme sahip öğretmenlerden anlamlı derecede yüksek olduğu, 1-5 
yıl kıdeme sahip öğretmenlerin algılarının, 16-20 yıl kıdeme sahip öğretmenlerden anlamlı derecede yüksek olduğu bulunmuştur.

Okul Öncesi Öğretmenlerinin Üstün Yeteneklilerin Eğitimine Yönelik Bir Eğitime Katılıp Katılmama Durumlarına Göre Üstün Yetenekli Öğrencilere Yönelik Algılarının Karşılaştırılması

Okul öncesi öğretmenlerin üstün yetenekli öğrencilere yönelik eğitime katılım katılmama durumlarına göre üstün yetenekli öğrencilere yönelik algılarının anlamlı bir şekilde farklılaşıp farklılaşmadığını belirlemek için bağımsız $\mathrm{t}$ - testi analizi kullanılmıştır. Tablo 4'te okul öncesi öğretmenlerinin eğitime katılıp katılmama durumuna göre üstün yetenekli öğrencilere yönelik algılarıyla ilgili betimsel veriler verilmiştir.

Tablo 4. Okul Öncesi Öğretmenlerinin Üstün Yeteneklilerin Eğitimine Yönelik Bir Eğitime Kathlıp Katılmama Durumlarına Göre Üstün Yetenekli Öğrencilere Yönelik Algı Genel Ortalama Puanlarının Karşılaştırılması

\begin{tabular}{|c|c|c|c|c|c|c|c|c|}
\hline Boyut & Eğitime Katılım & $\mathbf{N}$ & $\bar{X}$ & $\mathbf{S}$ & Sd & $\mathbf{T}$ & $\mathbf{p}$ & Açıklama \\
\hline \multirow{2}{*}{ Öğrenme İstekliliği } & Evet & 61 & 4.31 & 0.30 & \multirow{2}{*}{98} & \multirow{2}{*}{3.83} & \multirow{2}{*}{0.00} & $p<0.05$ \\
\hline & Hayır & 39 & 3.97 & 0.59 & & & & Fark anlamlı \\
\hline \multirow{2}{*}{ Ifade Etme Özellikleri } & Evet & 61 & 4.29 & 0.22 & \multirow{2}{*}{98} & \multirow{2}{*}{4.97} & \multirow{2}{*}{0.00} & $p<0.05$ \\
\hline & Hayır & 39 & 3.91 & 0.52 & & & & Fark anlamlı \\
\hline \multirow{2}{*}{ Kişilik Özellikleri } & Evet & 61 & 4.03 & 0.16 & \multirow{2}{*}{98} & \multirow{2}{*}{0.21} & \multirow{2}{*}{0.83} & $p>0.05$ \\
\hline & Hayır & 39 & 4.02 & 0.37 & & & & Fark anlamsız \\
\hline \multirow{2}{*}{ Zihinsel Özellikleri } & Evet & 61 & 4.70 & 0.25 & \multirow{2}{*}{98} & \multirow{2}{*}{5.85} & \multirow{2}{*}{0.00} & $p<0.05$ \\
\hline & Hayır & 39 & 4.12 & 0.71 & & & & Fark anlamlı \\
\hline \multirow{2}{*}{ Öğrenme Özellikleri } & Evet & 61 & 4.23 & 0.39 & \multirow{2}{*}{98} & \multirow{2}{*}{1.83} & \multirow{2}{*}{0.07} & $p<0.05$ \\
\hline & Hayır & 39 & 4.07 & 0.49 & & & & Fark anlamlı \\
\hline \multirow{2}{*}{ Genel Puan } & Evet & 61 & 4.29 & 0.22 & \multirow{2}{*}{98} & \multirow{2}{*}{4.10} & \multirow{2}{*}{0.00} & $p<0.05$ \\
\hline & Hayır & 39 & 4.00 & 0.48 & & & & Fark anlamlı \\
\hline
\end{tabular}

Tablo 4'te görüldüğü gibi, daha önceden eğitime katıldığını belirten öğretmenlerin üstün yetenekli öğrencilerin 'öğrenme istekliliğine' yönelik algı puanları daha once eğitime katıldığını belirten öğretmenler için $(\bar{X}=4.31 \mathrm{~S}=.30)$ ve daha önceden eğitime katılmadığını belirten öğretmenlerinin algı puan ortalamaları $(\bar{X}=3.97, S=.59)$ olarak bulunmuştur. Bu boyutta daha önceden eğitime katılan ve katılmayan öğretmenlerin algıları arasında anlamlı bir farklılık görülmüştür ( $t=3.83, p<0.05)$. Eğitime katıldığını belirten öğretmenlerin üstün yetenekli öğrencilerin ‘öğrenme istekliliği' boyutundaki algıları katılmayanlardan daha yüksektir.

Okul öncesi öğretmenlerin üstün yetenekli öğrencilerin 'ifade etme özelliklerine' ilişkin algı puanları ortalamaları ise daha önceden eğitime katıldığını belirten öğretmenler için ( $\bar{X}=4.29, S=.22)$ ve daha önceden eğitime katılmadığını belirten için ise ( $\bar{X}=3.91, \mathrm{~S}=.52)$ olarak bulunmuştur. Bu boyutta da daha önceden eğitime katılan ve katılmayan öğretmenlerin algıları arasında anlamlı bir farklılık görülmüştür ( $t=4.97, p<0.05)$. Eğitime katıldığını belirten öğretmenlerin üstün yetenekli öğrencilerin 'ifade etme özellikleri' boyutundaki algıları katılmayanlardan daha yüksektir.

Okul öncesi öğretmenlerin üstün yetenekli öğrencilerin kişilik özelliklerine ilişkin algı puanları ortalamaları ise daha önceden eğitime katıldığını belirten öğretmenler için $(\bar{X}=4.03, S=.16)$ ve daha önceden eğitime katımadığını belirten için ise ( $\bar{X}=4.02, \mathrm{~S}=.37$ ) olarak bulunmuştur. Bu boyutta da daha önceden eğitime katllan ve katılmayan öğretmenlerin algıları arasında anlamlı bir farklılık görülmemiştir ( $t=0.21, p>0.05)$.

Okul öncesi öğretmenlerin üstün yetenekli öğrencilerin zihinsel özelliklerine ilişkin algı puanları ortalamaları ise daha önceden eğitime katıldığını belirten öğretmenler için $(\bar{X}=4.70, S=.25)$ ve daha önceden eğitime katılmadığını belirten için ise ( $\bar{X}=4.12, \mathrm{~S}=.71)$ olarak bulunmuştur. Bu boyutta da daha önceden eğitime kattlan ve katılmayan öğretmenlerin algıları arasında anlamlı bir farklııı görülmüştür ( $\mathrm{t}=5.85, \mathrm{p}<0.05)$. Eğitime katıldığını belirten öğretmenlerin üstün yetenekli öğrencilerin 'zihinsel özellikleri' boyutundaki algıları katılmayanlardan daha yüksektir.

Okul öncesi öğretmenlerin üstün yetenekli öğrencilerin öğrenme özelliklerine ilişkin algı puanları ortalamaları ise daha önceden eğitime katıldığını belirten öğretmenler için $(\bar{X}=4.23, \mathrm{~S}=.39)$ ve daha önceden eğitime katılmadığını belirten için ise ( $\bar{X}=4.07, S=.49$ ) olarak bulunmuştur. Bu boyutta da daha önceden eğitime kattlan ve katıl- 
mayan öğretmenlerin algıları arasında anlamlı bir farklılık görülmüştür ( $t=1.83, p<0.05)$. Eğitime katıldığını belirten öğretmenlerin üstün yetenekli öğrencilerin 'öğrenme özellikleri' boyutundaki algıları katılmayanlardan daha yüksektir.

Okul öncesi öğretmenlerinin üstün yetenekli öğrencilere ilişkin toplam algı puanları ortalamaları ise daha önceden eğitime katıldığını belirten öğretmenler için $\quad(\bar{X}=4.29, \mathrm{~S}=.22)$ ve daha önceden eğitime katılmadığını belirten için ise $(\bar{X}=4.00, S=.48)$ olarak bulunmuştur. Bu boyutta da daha önceden eğitime katllan ve katılmayan öğretmenlerin algıları arasında anlamlı bir farklılık görülmüştür ( $t=4.10, p<0.05)$. Eğitime katıldığını belirten öğretmenlerin üstün yetenekli öğrencilere yönelik algıları katılmayanlardan daha yüksektir.

Okul Öncesi Öğretmenlerinin Üstün Yetenekli Öğrenciler ile ilgili Kaynaklara Nereden Ulaşttkları ile Üstün Yetenekli Öğrencileri Algılamalarının Karşılaştırılması

Okul öncesi öğretmenlerinin kaynaklara hangi yöntemleri kullanlarak ulaştıkları ile ilgili üstün yetenekli öğrencilere yönelik algılarının anlamlı bir şekilde farklılaşıp farklılaşmadığını belirlemek için One Way ANOVA yapılmıştır. Tablo 5 'te öğretmenlerin kaynaklara nereden ulaşttklarına göre üstün yetenekli öğrencilere yönelik algılarıyla ilgili betimsel veriler verilmiştir.

Tablo 5. Okul Öncesi Öğretmenlerinin Kaynaklara Nereden Ulaştıklarına Göre Üstün Yetenekli Öğrencilere Yönelik Algı Genel Ortalama Puanlarının Karşılaştııılması

\begin{tabular}{|c|c|c|c|c|c|c|c|c|}
\hline Boyut & & $\mathbf{N}$ & $\bar{X}$ & S & df & $\mathbf{F}$ & p & Açıklama \\
\hline \multirow{4}{*}{ Öğrenme İstekliliği } & İnternetten & 52 & 4.34 & 0.32 & \multirow{4}{*}{2} & \multirow{4}{*}{9.314} & \multirow{4}{*}{0.000} & \multirow{4}{*}{$\begin{array}{c}p<0.05 \\
\text { Fark anlamlı }\end{array}$} \\
\hline & Kitaplardan & 31 & 3.92 & 0.64 & & & & \\
\hline & Uzmanlardan & 17 & 4.12 & 0.19 & & & & \\
\hline & Total & 100 & 4.17 & 0.46 & & & & \\
\hline \multirow{4}{*}{ Ifade Etme Özellikleri } & Internetten & 52 & 4.32 & 0.22 & \multirow{4}{*}{2} & \multirow{4}{*}{12.790} & \multirow{4}{*}{0.000} & \multirow{4}{*}{$\begin{array}{c}p<0.05 \\
\text { Fark anlamlı }\end{array}$} \\
\hline & Kitaplardan & 31 & 3.90 & 0.58 & & & & \\
\hline & Uzmanlardan & 17 & 3.99 & 0.11 & & & & \\
\hline & Total & 100 & 4.14 & 0.41 & & & & \\
\hline \multirow[b]{2}{*}{ Kişilik } & Internetten & 52 & 4.04 & 0.18 & \multirow{4}{*}{2} & \multirow{4}{*}{.794} & \multirow{4}{*}{.455} & \multirow{4}{*}{$\begin{array}{c}\mathrm{p}>0.05 \\
\text { Fark anlamsı }\end{array}$} \\
\hline & Kitaplardan & 31 & 3.98 & 0.27 & & & & \\
\hline \multirow{2}{*}{ Özellikleri } & Uzmanlardan & 17 & 4.08 & 0.42 & & & & \\
\hline & Total & 100 & 4.03 & 0.26 & & & & \\
\hline \multirow{4}{*}{ Zihinsel Özellikleri } & İnternetten & 52 & 4.73 & 0.25 & \multirow{4}{*}{2} & \multirow{4}{*}{16.584} & \multirow{4}{*}{0.000} & \multirow{4}{*}{$\begin{array}{c}p<0.05 \\
\text { Fark anlamlı }\end{array}$} \\
\hline & Kitaplardan & 31 & 4.04 & 0.72 & & & & \\
\hline & Uzmanlardan & 17 & 4.27 & 0.62 & & & & \\
\hline & Total & 100 & 4.47 & 0.56 & & & & \\
\hline \multirow{4}{*}{ Öğrenme Özellikleri } & Internetten & 52 & 4.27 & 0.41 & \multirow{4}{*}{2} & \multirow{4}{*}{4.116} & \multirow{4}{*}{0.019} & \multirow{4}{*}{$\begin{array}{c}p<0.05 \\
\text { Fark anlamlı }\end{array}$} \\
\hline & Kitaplardan & 31 & 3.99 & 0.50 & & & & \\
\hline & Uzmanlardan & 17 & 4.17 & 0.28 & & & & \\
\hline & Total & 100 & 4.17 & 0.43 & & & & \\
\hline \multirow{4}{*}{ Genel Puan } & İnternetten & 52 & 4.31 & 0.23 & \multirow{4}{*}{2} & \multirow{4}{*}{9.405} & \multirow{4}{*}{0.000} & \multirow{4}{*}{$\begin{array}{c}\mathrm{p}<0.05 \\
\text { Fark anlamlı }\end{array}$} \\
\hline & Kitaplardan & 31 & 4.00 & 0.51 & & & & \\
\hline & Uzmanlardan & 17 & 4.05 & 0.22 & & & & \\
\hline & Total & 100 & 4.17 & 0.37 & & & & \\
\hline
\end{tabular}

Tablo 5'te görüldüğü gibi, okul öncesi öğretmenlerinin üstün yeteneklilerle ilgili bilgiye ulaşmada ne tür kaynak kullanma yöntemlerine göre üstün yetenekli öğrencilerin 'öğrenme istekliliği' boyutuna yönelik algıları arasında anlamlı bir farklılık bulunmuştur ( $F=9.314, p<0,05)$. Scheffe testi sonucu internetten cevabı veren öğretmenlerin algılarının, ( $\bar{X}=4.34, \mathrm{~S}=.32)$, kitaplardan cevabını veren öğretmenlerden ( $\bar{X}=3.92, \mathrm{~S}=.64)$ anlamlı derecede yüksek olduğu bulunmuştur. Üstün yeteneklilerle ilgi bilgiye internetten ulaşan öğretmenlerin algılarının, kitaptan ulaşan öğretmenlerden daha yüksek olduğu görülmüştür.

Okul öncesi öğretmenlerinin üstün yeteneklilerle ilgi bilgiye ulaşmada kaynak türlerine göre üstün yetenekli öğren- 
cilerin 'ifade etme özellikleri' boyutundaki algıları arasında anlamlı bir farklılık bulunmuştur ( $F=12.970, p<0,05)$. Scheffe testi sonucu internetten cevabı veren öğretmenlerin algılarının $(\bar{X}=4.32, \mathrm{~S}=.18)$, kitaptan ulaşan öğretmenlerden daha yüksek olduğu görülmüştür ( $\bar{X}=3.90, S=.27)$. Okul öncesi öğretmenlerinin kaynaklara ulaşma yöntemlerine göre üstün yetenekli öğrencilerin 'kişilik özellikleri' boyutundaki algıları arasında anlamlı bir farklılık bulunmamıştır ( $F=.794$, $\mathrm{p}>0,05)$.

Okul öncesi öğretmenlerinin üstün yeteneklilerle ilgi bilgiye ulaşma kaynak türlerine göre üstün yetenekli öğrencilerin 'zihinsel özellikleri' boyutundaki algıları arasında anlamlı bir farklılık bulunmuştur ( $F=16.584, p<0,05)$. Scheffe testi sonucu internetten cevabı veren öğretmenlerin algılarının ( $\bar{X}=4.73, \mathrm{~S}=.25)$, kitaptan ulaşan öğretmenlerden daha yüksek olduğu görülmüştür ( $\bar{X}=4.04, \mathrm{~S}=.72$ ).

Okul öncesi öğretmenlerinin üstün yeteneklilerle ilgi bilgiye ulaşma kaynak türlerine göre üstün yetenekli öğrencilerin 'öğrenme özellikleri' boyutundaki algıları arasında anlamlı bir farklılık bulunmuştur $(F=4.116, p<0,05)$. Scheffe testi sonucu internetten cevabı veren öğretmenlerin algılarııı ( $\bar{X}=4.27, \mathrm{~S}=.41)$ kitaptan ulaşan öğretmenlerden daha yüksek olduğu görülmüştür ( $\bar{X}=3.99, \mathrm{~S}=.52$ ).

Okul öncesi öğretmenlerinin üstün yeteneklilerle ilgi bilgiye ulaşma kaynak türlerine göre üstün yetenekli öğrencilerin genel algıları arasında anlamlı bir farklılık bulunmuştur ( $F=9.405, p<0,05)$. Scheffe testi sonucu internetten cevabı veren grubun ortalamasının diğer grupların ortalamasından anlamlı derecede yüksek olduğu bulunmuştur.

\section{Okul Öncesi Öğretmenlerinin Üstün Yetenekli Öğrencilere Yönelik Eğitim İhtiyaçları}

Bu başlık altında, okul öncesi öğretmenlerinin üstün yetenekli öğrencilere yönelik eğitim ihtiyaçlarına ilişkin bulgular ve yorumlar sırasıyla açıklanmıştır. Okul öncesi öğretmenlerinin üstün yetenekli öğrencilere yönelik eğitim ihtiyacı anketi’ ne ilişkin betimsel istatistiksel sonuçları ise tablo 6'da verilmiştir.

Tablo 6. Okul Öncesi Öğretmenlerinin Üstün Yetenekli Öğrencilere Yönelik Eğitim İhtiyaçları Ortalama ve Standart Sapma Değerleri

\begin{tabular}{|c|c|c|c|c|c|}
\hline Anket Maddeleri & $\mathrm{N}$ & Min & Mak & $\bar{X}$ & S \\
\hline 1.Üstün zekâlı /yetenekliler ile ilgili bilgiye ulaşmaya & 100 & 2 & 3 & 2.65 & .479 \\
\hline 2.Üstün zekâlı /yeteneklileri tespit etmeye & 100 & 1 & 3 & 2.62 & .632 \\
\hline 3.Üstün zekâlı /yeteneklilere uygun öğretim yöntemlerini seçmeye & 100 & 1 & 3 & 2.67 & .620 \\
\hline 4.Üstün zekâlı /yeteneklilere uygun öğretim yöntemlerini uygulamaya & 100 & 2 & 3 & 2.75 & .435 \\
\hline 5.Üstün zekâlı /yeteneklilere uygun seçeceğim yaklaşımlara & 100 & 2 & 3 & 2.70 & .461 \\
\hline 6.Üstün zekâlı /yeteneklilere uygun seçtiğim yaklaşımları uygulamaya & 100 & 1 & 3 & 2.83 & .473 \\
\hline 7.Üstün zekâlı /yeteneklilerle iletişim kurmaya & 100 & 1 & 3 & 2.79 & .574 \\
\hline 8.Üstün zekâlı /yeteneklilere yönelik öğretim hedefleri belirlemeye & 100 & 2 & 3 & 2.91 & .288 \\
\hline 9.Üstün zekâlı /yeteneklilerin aileleri ile iletişim kurmaya & 100 & 1 & 3 & 2.77 & .510 \\
\hline 10.Üstün zekâlı /yeteneklilerle normal öğrencilere bir arada eğitim vermeye & 100 & 1 & 3 & 2.64 & .628 \\
\hline 11.Üstün zekâlı /yeteneklilerin sınıftaki davranışlarının yönetimi ile ilgili bilgiye & 100 & 1 & 3 & 2.74 & .597 \\
\hline 12.Üstün zekâlı /yeteneklilere yönelik öğretim etkinlikleri düzenlemeye & 100 & 1 & 3 & 2.78 & .504 \\
\hline 13.Üstün zekâlı / yeteneklilere rehberlik etmeye & 100 & 1 & 3 & 2.83 & .473 \\
\hline 14.Üstün zekâlı /yeteneklilerle normal öğrencilere nasıl davranacağım konusunda bilgiye & 100 & 1 & 3 & 2.73 & .529 \\
\hline 15.Üstün zekâlı /yeteneklilerle ilgili uzmanlığı olan kişilerle iletişim kurmaya & 100 & 1 & 3 & 2.82 & .479 \\
\hline 16.Sınıflarında üstün zekâlı /yetenekli öğrencisi olan diğer öğretmenlerle iletişim kurmaya & 100 & 1 & 3 & 2.78 & .504 \\
\hline 17.Sınıflarında üstün zekâlı /yetenekli öğrencisi olan diğer öğretmenlerle deneyimlerini paylaşmaya & 100 & 1 & 3 & 2.88 & .433 \\
\hline 18.Üstün zekâlı / yeteneklilerin gelişim psikolojilerini değerlendirmeye & 100 & 2 & 3 & 2.86 & .349 \\
\hline 19.Üstün zekâlı /yeteneklilerin öğrenme profillerini değerlendirmeye & 100 & 2 & 3 & 2.96 & .197 \\
\hline 20.Üstün zekâlı /yeteneklilere uygun öğrenme ortamı yaratmaya & 100 & 1 & 3 & 2.83 & .473 \\
\hline 21.Üstün zekâlı /yeteneklilerin öğrenme ihtiyaçlarını belirlemeye & 100 & 2 & 3 & 2.92 & .273 \\
\hline 22.Üstün zekâlı /yeteneklilere aktarılacak içeriğin onların düzeyine uygunluğunu belirlemeye & 100 & 2 & 3 & 2.96 & .197 \\
\hline 23.Üstün zekâlı/yeteneklilere uygun ölçme değerlendirme yapmaya & 100 & 2 & 3 & 2.91 & .288 \\
\hline 24.Üstün zekâlı /yeteneklilere uygun ölçme araçlarını seçmeye & 100 & 2 & 3 & 2.92 & .273 \\
\hline 25.Üstün zekâlı /yeteneklilerin öğretim sürecine uygun materyaller seçmeye & 100 & 1 & 3 & 2.84 & .545 \\
\hline Ortalama & & & & 2.80 & .364 \\
\hline
\end{tabular}


Tablo 6'da görüldüğü gibi, okul öncesi öğretmenlerinin üstün yetenekli öğrencilerle ilgili genel eğitim ihtiyaçları aritmetik ortalama ve standart sapma puanları $(\bar{X}=2.80, \mathrm{~S}=.364)$ olarak belirlenmiştir. Bu sonuç okul öncesi öğretmenlerinin orta düzeyde eğitime ihtiyaçlarının olduğunu göstermektedir. Öğretmenlerin en fazla üstün zekâlı/yeteneklilerin öğrenme profillerini değerlendirmeye $(\bar{X}=2.96, \mathrm{~S}=0.197)$, üstün zekâlı/yeteneklilere aktarılacak içeriğin onların düzeyine uygunluğunu belirlemeye ( $\bar{X}=2.96, \mathrm{~S}=0.197)$, Üstün zekâlı /yeteneklilerin öğrenme ihtiyaçlarını belirlemeye $(\bar{X}$ $=2.92, \mathrm{~S}=0.273$ ) yönelik konularda eğitime ihtiyaçları olduğu görülürken, öğretmenlerin en az eğitime ihtiyaç hissettiği ifadeler ise üstün zekâlı/yeteneklileri tespit etmeye ( $\bar{X}=2.62, \mathrm{~S}=0.632)$, üstün zekâlı /yeteneklilerle normal öğrencilere bir arada eğitim vermeye $(\bar{X}=2.64, \mathrm{~S}=0.628)$, üstün zekâlı /yetenekliler ile ilgili bilgiye ulaşmadır $(\bar{X}=2.65, \mathrm{~S}=0.479)$.

\section{Tartışma ve Sonuç}

Bu bölümde, öğretmenlerin üstün yetenekli öğrencilere yönelik algı ve eğitim ihtiyaçlarının belirlenmesi amacıyla gerçekleştirilen araştırmanın sonuçlarına ve sonuçlara bağlı olarak geliştirilen tartışmalara yer verilmiştir.

Okul öncesi öğretmenlerinin üstün yetenekli öğrencilere yönelik algılarının ortalama puanı "katlıyorum" sınırları içerisinde belirlenmiştir. Bu bulgu, okul öncesi öğretmenlerinin üstün yetenekli öğrencilere yönelik algılarının kesinlikle katılıyorum aralığında olmasa dahi olumlu yönde olduğu şeklinde yorumlanabilir. Bu bulgu sonucunu destekler yönde Demirok (2012), yılında yapmış olduğu araştırmasında ilköğretim öğretmenlerinin üstün yetenekli öğrencilere yönelik algılarının da katılıyorum sınırları arasında olumlu yönde olduğunu belirtmiştir. Dinarlı (2016), özel eğitim öğretmenleri ile yapmış olduğu çalışmasında, özel eğitim öğretmenlerinin üstün yetenekli öğrencilere yönelik algılarının ortalama puanı "katılıyorum" sınırları içerisinde belirlenmiştir yani özel eğitim öğretmenlerinin üstün yetenekli öğrencilere yönelik algılarının kesinlikle katılıyorum aralığında olmasa dahi olumlu yönde olduğu sonucuna ulaşmıştr. Yine Bohner ve Wanke (2002), yapmış oldukları araştırmada, kesin ve açık bilgi eksikliğinin algıyı olumsuz şekilde etkilediğini ortaya koymuşlardır. Bu anlamda, kesinlikle kathlıyorum düzeyinde olmamasının nedeninin bir tanesinin özel eğitim öğretmenlerinin üstün yetenekli öğrencilerle ilgili bilgi eksikliğinden kaynaklanmış olabileceği şeklinde düşünülebilir. Moore (2009), ilköğretim sınıflarında akademik üstünlüğe yönelik öğretmen algıları konusunda yaptığı metafor çalışmasında ise, nitel araştırma sonucunda öğretmenlerin üstün yetenekli eğitimine ve üstün yetenekli çocukların tanımlanması konusunda pozitif yönde düşüncelere sahip oldukları ortaya çıkmıştır.

Okul öncesi öğretmenlerinin üstün yetenekli öğrencilerin "öğrenme istekliliği”, "ifade etme özellikleri", "kişilik özellikleri", "öğrenme özellikleri", "zihinsel özellikleri" boyutlarına ilişkin algı puanları ortalamalarına cinsiyetlerine göre bakıldığında ise kadın ve erkek okul öncesi öğretmenlerinin algıları arasında anlamlı bir farklılık görülmemiştir. Okul öncesi öğretmenlerinin genel olarak üstün yetenekli öğrencilere yönelik algıları incelendiği zaman kadın okul öncesi öğretmenleri ile erkek okul öncesi öğretmenlerinin algıları arasında anlamlı bir farklılık olmadığı saptanmıştır. Bu sonuç, öğretmenlerin üstün yetenekli öğrencilere yönelik algılarını cinsiyetlerine göre etkilemediği şeklinde yorumlanabilir. Dinarlı (2016), da özel eğitim öğretmenlerinin genel olarak üstün yetenekli öğrencilere yönelik algılarını cinsiyet değişkeninde incelendiği nde kadın özel eğitim öğretmenleri ile erkek özel eğitim öğretmenlerinin algıları arasında anlamlı bir farklılık olmadığı saptanmıştır. Bu Sonuç, öğretmenlerin cinsiyetlerinin üstün yetenekli öğrencilere yönelik algılarını etkilemediği şeklinde yorumlanabilir.

Okul öncesi öğretmenlerinin üstün yetenekli öğrencilere yönelik algı genel ortalama puanlarının yaşlarına göre karşılaştırılma sonuçlarına bakıldığında ise okul öncesi öğretmenlerinin üstün yetenekli öğrencilerin "öğrenme istekliliği”, "ifade etme özellikleri”, "öğrenme özellikleri”, "zihinsel özellikleri” boyutlarına ve genel algılarına ilişkin algılarında yaşlarına göre anlamlı bir fark olduğu belirlenmiştir. Genç yaştaki okul öncesi öğretmenlerinin algı puanlarının daha yüksek olduğu gözlemlenmiştir. Bu anlamda genç yaştaki okul öncesi öğretmenlerinin yaşlarının üstün yetenekli öğrencilere yönelik algılarını olumlu yönde etkilediği şeklinde yorumlanabilir. Bu sonucu desteklemeyen nitelikte Demirok, (2012)' de yaptığı araştırmasında, ilköğretim öğretmenlerinin yaşlarının üstün yetenekli öğrencilere yönelik algılarında bir farklılık yaratmadığı sonucuna ulaşmıştır. Mavi (2016), ise rehber öğretmenlerin yaşlarına göre üstün yetenekli öğrencilere yönelik görüşleri arasında anlamlı bir farklılık bulmuştur. Görüş toplam puanı açısından en yüksek değere sahip gruplar 31-40 yaş arası olarak ve 21-30 yaş grubu öğretmenlerin üstün yetenekli öğrencilere yönelik görüşlerinin diğer yaş grubu öğretmenlerden daha olumsuz olduğu sonucuna varılmıştır.

Okul öncesi öğretmenlerinin göre üstün yetenekli öğrencilere yönelik algı genel ortalama puanlarının mesleki kıdemlerine karşılaştrılma sonuçlarına bakıldığında okul öncesi öğretmenlerinin mesleki kıdemlerine göre üstün yetenekli öğrencilerin, "öğrenme istekliliği", "ifade etme özellikleri", "kişilik özellikleri", "öğrenme özellikleri", "zihinsel özellikleri" boyutlarına ve genel algılarına ilişkin algı puanları arasında anlamlı bir fark olduğu belirlenmiştir. Bu sonuca göre okul öncesi öğretmenlerinin üstün yetenekli öğrencilere yönelik algılarında mesleki kıdemlerinin olumlu bir etki

| Kastamonu Eğitim Dergisi, 27(5), 2019| 
yarattğı yönünde yorumlanabilir. Algı toplam puanı açısından en yüksek değere sahip iki grup sırasıyla 6-10 yıl ve 1-5 yıl arası kıdeme sahip öğretmenlerdir. Mesleğe yeni başlayan öğretmenlerin algı puanlarının daha yüksek olduğu gözlemlenmiştir. Bu sonucu destekleyen bir şekilde Demirok (2012), yapmış olduğu çalışmasında ilköğretim öğretmenlerinin mesleki kıdemlerine göre üstün yetenekli öğrencilere yönelik algılarında mesleklerinde yeni olan öğretmenlerin daha olumlu algıya sahip olduğu sonucuna ulaşmıştr.

Okul öncesi öğretmenlerinin daha önceden bir eğitime katlıp katılma durumlarına göre üstün yetenekli öğrencilere yönelik algı genel ortalama puanlarının karşılaştıılma sonuçlarına bakıldığında, üstün zekâ eğitimine yönelik bir eğitime katılan ve katılmayan öğretmenlerin üstün yetenekli öğrencilerin "öğrenme istekliliği", "ifade etme özellikleri", "öğrenme özellikleri", "zihinsel özellikleri" boyutlarına ve genel algılarına ilişkin algı puanları arasında anlamlı bir fark olduğu belirlenmiştir. Algı toplam puanı açısından daha önceden eğitime katıldığını belirten öğretmenlerin puanları daha yüksektir. Bu anlamda öğretmenlerin hizmet içi eğitime katıldığından dolayı algılarında bir farklılık yaratmış olduğu düşünülebilir. Ayrıca, Cheung ve Phillipson (2008) tarafindan “Hong Kong'daki Üstün Yetenekli Öğrencilerin Öğretmenlerinin Yeterlik ve Karakteristik Özellikleri" konulu deneysel bir araştırma yapılmıştır. Çalışmanın sonucunda, iki grup öğretmenin (üstün yeteneklilerin eğitiminde deneyimli ve deneyimli olmayan) öğrencilere danışmanlık yapma konusundaki yeterlik ve karakteristik özelliklerinde belirgin farklar olduğunu ortaya çıkarmıştır.

Okul öncesi öğretmenlerinin üstün yetenekli öğrencilere yönelik algı genel ortalama puanlarının kaynaklara ulaşma yöntemlerine göre karşılaştırılma sonuçlarına bakıldığında "öğrenme istekliliği”, "ifade etme özellikleri”, "öğrenme özellikleri", "zihinsel özellikleri" boyutlarına ve genel algılarına ilişkin algı puanları arasında anlamlı bir fark olduğu belirlenmiştir. Algı toplam puanı açısından interneti kullanan öğretmenlerin puanları daha yüksektir.

Araştırmaya katılan okul öncesi öğretmenlerinin üstün yetenekli öğrencilere yönelik eğitim ihtiyaçlarına bakıldığında okul öncesi öğretmenlerinin üstün yetenekli öğrencilere yönelik eğitim ihtiyaçlarının ortalama puanı "çok ihtiyaç hissediyorum" sınırları içerisinde belirlenmiştir. Yine, Mavi (2016), rehber öğretmenler ile yapmış olduğu çalışmasında rehber öğretmenlerin genel olarak üstün yetenekli öğrenciler ile ilgili tüm konularda çok fazla eğitim ihtiyaçlarının olduğunu belirlemiştir. Bu bulguya göre, okul öncesi öğretmenlerinin üstün yetenekli öğrencilerle ilgili yeterli bilgiye sahip olmadıkları ve eğitime duydukları söylenebilir. Bu eksikliğin üstün yetenekli öğrencilerin eğitim sürecini olumsuz etkilememesi için hem hizmet öncesi hem de hizmet içi eğitim sürecinde bu konu üzerinde önemle durulması gerekmektedir.

\section{Kaynakça}

Ataman, A. (2011). Özel Gereksinimli Çocuklar ve Özel Eğitime Giriş. Ankara: Gündüz Eğitim ve Yayınları.

Baykoç, N. (2014). Üstün Akıl, Zekâ, Deha, Yetenek, Dâhiler-Savantların Gelişimleri Ve Eğitimleri. Ankara: Vize Yayıncılık.

Blackburn, A., \& Erickson, D. B. (1986). Predictale Crises of the Gifted Students. Journal of Counselling and Development, 64, 5253.

Bozgeyikli, H., Doğan, H., \& Işıklar, A. (2010). Üstün Yetenekli Öğrencilerin Mesleki Olgunluk Düzeyleri ile Algıladıkları Sosyal Destek Düzeyleri Arasındaki Ilişkinin İncelenmesi. Sosyal Bilimler Enstitüsü Dergisi,28, 133-149.

Burger, J. M. (2006). Kişilik. İstanbul: Kaknüs Yayınları.

Coşar, G., Çetinkaya, Ç., \& Çetinkaya, Ç. (2015). Investigating the preschool training for gifted and talented students on gifted school teachers' view. Journal for the Education of Gifted Young Scientists, 3,13-21.

Cheung, H. Y., \& Phillipson, S. N. (2008). Teachers of Gifted Students in Hong Kong: Conpetencies and Characteristics. The Asia-Pacific Education Researcher, 17, 143-156.

Çapan, E. B. (2010). Öğretmen Adaylarının Üstün Yetenekli Öğrencilere Illişkin Metaforik Algıları. Uluslararası Sosyal Araştrrmalar Dergisi, 3,140-154.

Dağlıŏlu, H. E. (2010). Üstün Yetenekli Çocukların Eğitiminde Öğretmen Yeterlilikleri ve Özellikleri. Milli Eğitim Dergisi,186, 72-82.

Dağlıŏlu, H. E. (2014). Erken Çocukluk Döneminde Üstün Yetenekli Çocuklar. İ. H. Diken (Ed.), Erken çocukluk eğitimi (s. 345-502). Ankara: PegemA Yayıncilık.

Demirok, M., \& Ozcan, D. (2016). The Scale of Teacher Perception of Gifted Students: a Validity and Reliability Study. Croatian Journal of Education, 18, 817-836.

Demirok, M. (2012). Öğretmeni Yönetici, Denetmen ve Velilerin Üstün Yetenekli Öğrencilere Yönelik, Algı, Görüş ve Eğitim İhtiyaçlarının Belirlenmesi. (Doktora tezi).Yakın Doğu Üniversitesi, Eğitim Bilimleri Enstitüsü, Lefkoşa.

Dinarlı, J. (2016). Özel eğitim öğretmenlerin üstün zekâlı öğrencilere yönelik algı ve görüşlerinin belirlenmesi. (Yüksek lisans tezi). Yakın Doğu Üniversitesi, Eğitim Bilimleri Enstitüsü, Lefkoşa.

Dönmez, N. B., \& Kurt, S. (2004). Bebeklik ve Okul öncesi Dönemde Üstün Yetenekli Çocukların ve Ailelerinin Yönlendirilmesi. M. R. Şirin (Ed.), Türkiye Üstün Yetenekli Çocuklar Kongresi Bildiriler Kitabı, İstanbul: Çocuk Vakfı Yayınları. 
Gökdere, M., \& Çepni, S. (2003). Üstün Yetenekli Çocuklara Verilen Değerler Eğitiminde Öğretmenin Rolü, Değerler Eğitimi Dergisi, 1, 93-102.

Kaufman, J. C., Plucker, J. A., \& Russell, C. M. (2012). Identifying and Assessing Creativity as a Component of Giftedness, Journal of Psychoeducational Assessment, 30, 60-3.

Kontaş, H. (2010). Learning strategies of gifted elementary students. Elementary Education Online, 9, 1148-1158.

Levent, F. (2011). Üstün Yetenekli Çocukların Hakları El Kitabı, İstanbul: Çocuk Vakfi Yayınları.

Mavi, D. (2012). Rehber öğretmenlerin üstün zekâlı öğrencilere yönelik algı ve görüşlerinin belirlenmesi. (Yüksek lisans tezi).Yakın Doğu Üniversitesi, Eğitim Bilimleri Enstitüsü, Lefkoşa.

Metin, N. (2015). Üstün Yetenekli Çocukların Özellikleri ve Belirlenmesi. Üstün Yetenekliler Sempozyumu, Hasan Kalyoncu Üniversitesi.

Moore, E. J. (2009). Teacher perceptions of academic giftednees in elementary classroms: A study of metaphors. (Unpublished Ph. D. thesis). University of Cincinnati, Ohio.

Oktay, A. (2007). Yaşamın Sihirli Yılları: Okulöncesi Dönem. İstanbul: Epsilon Yayıncılık.

Palancı, M. (2004). Üstün Yetenekli Öğrencilerin Ihtiyaçlarını Karşılamaya Yönelik Gerçeklik Terapisi Temelli Okul Rehberlik Ve Psikolojik Danışma Hizmetleri Modeli: Üstün Yetenekli Çocuklar Bildiriler Kitabı, İstanbul: Çocuk Vakfı Yayınları, I. Türkiye Üstün Yetenekli Çocuklar Kongresi Yayın Dizisi.

Renzulli, J. S., \& Reis, S. M. (2008). Using the Schoolwide Enrichment Model to Enrich Curriculum for All Students. In Enriching Curriculum For All Students. Thousand Oaks, California: Corwin Press.

Rogers, K. (2009). Effective programs. London: Sage Publications.

Sak, U. (2009). Üstün Yetenekliler Eğitim Programı. Ankara: Maya Akademi Yayınları.

Sak, U. (2014). Üstün Zekâlılar, Özellikleri Tanılanmaları Eğitimleri. Ankara: Vize Yayıncılık.

Torrance, E. P., \& Goff, K. (1989). A Quiet Revolution. Journal of Creative Behavior, 23,136-145.

Uzun, M. (2004). Üstün Yetenekli Çocuklar El Kitabı. İstanbul: Çocuk Vakfı Yayınları.

VanTassel-Baska, J. (2005). Domain-Specific Giftedness: Applications in School and Life. In R. Sternberg \& J. Davidson (Eds.), Conceptions of Giftedness (pp. 358-376). Cambridge: Cambridge University Press.

Wright, B. J. (2008). A global conceptualization of giftedness: a comparison of us and indian gifted education programs. Master Thesis. Dominican University of California, California, United States. 